\title{
The Mercantile Form of Value and Its Place in Marx's Theory of the
}

\author{
Commodity $^{1}$ \\ Pablo Ahumada \\ Faculty of Commerce, Lincoln University \\ P.O. Box 84, Lincoln 7647 \\ Canterbury, NEW ZEALAND \\ Email: pablo.pahumada@gmail.com
}

\begin{abstract}
This paper re-interprets Marx's theory of the form of value in the context of his theory of the commodity. Building on the unresolved tension between Marx's concept of value and the specific character of the labour constituting itself as value in his theory of commodity production, this paper argues that Marx's is actually a theory of the mercantile form of value. Thus, it becomes evident that the process of realisation of material production in commodity production and the process giving rise to money are the same, and that they are only the material manifestation of the process of realisation of private and independent work as social labour. This characterises commodity production as the unity-in-difference of a material and a social moment, showing that Marx's mercantile form of value is the conceptualisation of Adam Smith's invisible hand. The paper also argues that Marx's is not the theory of a money commodity.
\end{abstract}

JEL Classification: B14, E40, P10

Keywords: Mercantile Form of Value, Commodity, Money, Marx

\footnotetext{
${ }^{1}$ I am grateful to Dr Paul Dalziel and Dr Gillis Maclean for their invaluable supervision in my masters' thesis and for helpful feedback on this paper. I am also grateful to Jenny Harvey, Dr Pablo Levín, Dr Ross Cullen, Dr Stefan Kesting and two anonymous referees for useful comments and discussion. The errors in this paper, however, are the sole responsibility of the author.
} 


\section{The Mercantile Form of Value and Its Place in Marx's Theory of the}

\section{Commodity}

\section{Introduction}

Marx's (1867) theory of the form of value has been largely overlooked in economics. Most of the debate on Capital $(1867,1885,1894)$ has focused one-sidedly on the law of labour value and the transformation of values into prices of production and has not taken into account that they presuppose the concept of form of value..$^{1}$ In the last twenty years, however, there has been a growing interest in the study of Marx's (1867) form of value ${ }^{2}$ encouraged by the publication in English of Marx's Grundrisse (Marx, 1857), The Making of 'Marx's Capital' (Rosdolsky, 1969) and On the Dialectics of the Value-Form (Backhaus, 1980). Nevertheless, as Kicillof \& Starosta (2007) highlight, this theoretical strand has been unable to surpass the unilateral formalistic approach of Rubin (1928) and therefore, it has failed to properly account for the material moment of commodity production and subsume the traditional approach to Marx. As a result, a widening gulf has ensued between Neo-Ricardians ${ }^{3}$ and what Kicillof \& Starosta (2007) label as "Formalist Marxism". ${ }^{4}$ In addition, and more importantly, the whole debate has lost sight of the issue that Marx's (1867) theory of the commodity addresses: how does material production become socially recognised in capitalism? This question is of fundamental importance, since capitalism is a global system of production in which material production is carried out privately and independently.

This paper deals with Marx's form of value as an inextricable component, together with his labour theory of value, of his theory of the commodity and as the concluding element of the answer to the above question. Moreover, and in agreement with Levín (1997), this paper argues that value is a generic concept related to reproducible products in general and that Marx's (1867) is actually a theory of the mercantile form of value. This becomes evident from the tension there is in Part I "Commodities and Money" of Capital I between the concept of value and the historically specific 
character of the labour constituting itself as value in commodity production. This tension implies that Marx's is not a critique of value in general but, in Levín's (1997) terms, of mercantile value, or of the historically specific mercantile form that value takes in commodity production. Thus, the following pages shed light on the process through which value as the mediating link between the pursuit of use value and the allocation of labour becomes objective and autonomous in commodity production and thereby disclose the specific aspect of commodity production.

This novel way of posing the problem allows us to re-conceptualise commodity production as the unity-in-difference of a material and a social moment (production and market exchange in usual economics parlance), highlighting the inherent uncertainty of the realisation of material production in capitalism. It also makes clear that neither moment has ontological primacy, as they are equally fundamental moments comprising the totality of commodity production. This breaks the false dichotomy between the subjectivist and the objectivist approaches to theorising commodity production, since, as Postone (1993) and Murray (1997) argue, commodity production pre-supposes both an objective and a subjective aspect..

This paper shows that the price form of the commodity is the specific mercantile form of expression of value as the substantiation of social labour. It is thus established that the mercantile form of value is the roundabout way in commodity production to allocate society's labour so that in the long run it meets society's needs. ${ }^{5}$ In other words, the mercantile form of value is the conceptualised explanation of Adam Smith's (1776) invisible hand. This, in turn, shows that the process through which material production becomes socially recognised in commodity production and the process giving rise to money are the same, and that they are only the material manifestation of the process of realisation of private and independent work as social labour. Unlike Marx (1867, 1885, 1894), the form of value theorists and the Neo-Ricardians, the approach outlined in this paper also fully appropriates Ricardo's (1817) concept of value and transcends it. In other words, this paper highlights that the notion of reproduction is central to the concept of value but also brings to light 
the specific character of the labour constituting itself as an autonomous objective social substance. Finally, it is argued that the intrinsic need to have an objective form of appearance of mercantile value in commodity production gives rise to money as the embodiment of purchasing power and that Marx's (1867) theory of money is not the theory of a money commodity.

Section 2 situates Marx's (1867) theory of the form of value with respect to the question of the opening paragraph and gives a brief overview of Marx's development of it. Section 3 analyses the tension between Marx's concept of value and the specificity that Marx accords it, and argues that value is a content of the commodity as generic as its quality of use value. Section 4 analyses Marx's theory of the form of value in detail and shows that it is actually a theory of the mercantile form of value, as a result historically specifying the type of value emerging as the autonomous and objective force regulating capitalist production. The progression through the mercantile forms of value, in turn, results from the logical unfolding of the concepts underpinning commodity production, starting, in Arthur's (2002) spirit, from the most abstract level and moving towards increasingly concrete determinations. The upshot is that although this paper deals with commodity production in its pervasive capitalist form, the form of capital itself, which is highly mediated, is not simply presupposed and consequently falls outside the scope of these pages. Therefore, production is referred to as commodity production. Section 5 discusses the implications of the theory of the mercantile form of value outlined in section 4. Section 6 offers some concluding remarks.

\section{Marx's Form of Value and Its Place in the Research Programme of Part I “Commodities and Money” of Capital I}

As argued above, the fundamental question underlying capitalism is how material production becomes realised or production proper. This is because the two moments comprising production (material and relational or social), ${ }^{6}$ which in pre-capitalist societies formed an immediate unity due to production being consciously organised, become two autonomous yet interlocking spheres in 
capitalism: material production and market exchange. The result is that material production in its immediacy is no longer production. The differentiation process that production undergoes in its capitalist form is illustrated in Figure 1 below. Marx's (1867) answer, as presented in chapter 1 of Capital, is that private and independent work becomes social labour as the substance of the value of commodities and that the value of commodities finds its necessary developed expression in their price form. Thus, Marx's answer can be broken down in two, as depicted in Figure 2: the transition from the exchange value of commodities to their value (the main theme of Classical Political Economy) and that from their value to their price form (Marx's own contribution). The second transition hinges on the first one (Ahumada, 2009; Campbell, 1997; Levín, 1997; Mattick Jr., 1993; Murray, 1993) and is the topic of this paper.

As a starting point Marx draws attention to the fact that commodities have a form of value common to them all and which presents a sharp contrast with their varied bodily forms: their money form. However, since this is already the developed form of value, the task is to trace its origin, which has been overlooked in both Neo-Classical Economics and Classical Political Economy. Marx points out that the riddle of the money form of the commodity and the riddle of commodity production are but two sides of the same coin.

In Marx's view, the exchange value relation between two commodities is their simplest social relation and already contains the basic differentiation between commodities and money or, in other words, between the relative and the equivalent forms of value. Only one commodity can express its value as something distinct from its bodily form. It does so by taking the relative form of value, that is, it equates itself to the second commodity. By this very act, the first commodity bestows upon the second the equivalent form of value. The second commodity cannot express its value actively but the fact that it is value is manifested in that it is equivalent to the first commodity, or directly exchangeable with it, thus acquiring the most basic trait of money, i.e. direct exchangeability. 
From the elementary or accidental form of value Marx derives the total or expanded form, in which each commodity equates its value to that of all other commodities through an endless chain of relative expressions of value. From this he derives the general form of value, in which every commodity but one expresses its value in the elementary form and in the same commodity, set aside spontaneously by all others, and which finally renders the value of all of them commensurable. The commodity set aside cannot express its value actively in relative form but is directly exchangeable with the rest of them. Marx argues that once one particular commodity has become the directly exchangeable commodity with exclusivity, the general form of value turns into the money form. The universal character of commodity production thereby gains an objective existence.

The following pages show that Marx's transition from the value of the commodity to the commodity's price form is conceptually correct but flawed in its details. The main flaw is that Marx does not fully develop the specificity of the commodity form of value and as a result, his theory of the form of value refers exclusively to the long run equilibrium. This raises some serious theoretical difficulties. If money is the developed form of expression of value, how can we account for the price of irreproducible commodities, which do not have value? What is the place of short run equilibrium prices, in general different from their long run counterparts, in a labour theory of value? Why does not all labour meeting an effective need constitute itself as value in commodity production? However, this paper also demonstrates that the gaps can be filled through a proper conceptualisation of Part I of the first volume of Capital.

\section{Generic and Specific Features of the Commodity}

This section highlights the unresolved tension there is between Marx's concept of value and the historical specificity that he accords it. ${ }^{7}$ This is nothing but the tension between the content of value and the historical specificity of the labour constituting itself as value in commodity production. In section 4 it will be argued that this unresolved tension is due to the fact that Marx failed to fully develop the concept of value, though this development is immanent to Part I of Capital I. ${ }^{8}$ 
For Marx $(1867,1885,1894)$ the key to comprehending commodity production lies in understanding the commodity as a historically specific form of the social product. Marx (1867) characterises the commodity as the unity-in-difference of use value and exchange value. However, for Marx the exchange value of a commodity is only the phenomenal form of appearance of its value. Thus, the commodity is the unity-in-difference of use value and value. The concept of use value that Marx advances is generic; in every society production involves the provision of goods capable of satisfying needs and wants. According to Marx, the specific feature of the commodity is that it is a value. He argues that commodity production is the first form in which the character of material wealth as being the product of labour appears stamped in the objects of utility as their value. However, in pages 76 through 79 of Capital Marx (1867 [1954]) makes crystal clear that there is nothing historically specific about either the content of value or the determination of its magnitude. The content of value is necessary labour without regard to its mode of expenditure labour abstracted from its materially concrete form of application - and the magnitude of value is determined by the quantity of this content. Marx illustrates this point with four examples: Robinson Crusoe, the serfdom system of the middle ages, the patriarchal industries of a peasant family and a hypothetical society of freely associated individuals.

Although Marx points out that Robinson's experiences do not involve social relations of production, he analyses them because they contain all that is essential to the determination of value.

Moderate though he [Robinson] be, yet some few wants he has to satisfy, and must do a little useful work of various sorts...In spite of the variety of his work, he knows that his labour, whatever its form, is the activity of one and the same Robinson... Necessity itself compels him to apportion his time accurately between his different kinds of work. Whether one kind occupies a greater space in his general activity than another, depends on the difficulties, greater or less as the case may be, to be overcome in attaining the useful effect aimed at...His stock-book contains a list of the objects of utility that belong to him, of the operations necessary for their production; and lastly, of the labour- 
time that definite quantities of those objects have, on an average, cost him (Marx, 1867 [1954, pp. 7677]).

In the above quotation it becomes evident that the concept of value is the mediating link between the pursuit of use value and the allocation of labour time. It is the pursuit of use value that determines the concrete forms in which Robinson applies his labour power in the process of reproduction of the material conditions for his survival. The allocation of his labour time among the different activities, in turn, is regulated by the quantities of labour necessary for him in order to replace the articles of his own wealth, which therefore determine the value of these articles for him.

By way of contrast, Marx's recourse to the middle ages refers to relations of personal servitude. Nevertheless, “[c]ompulsory labour is just as properly measured by time, as commodity-producing labour; but every serf knows that what he expends in the service of his lord, is a definite quantity of his own personal labour-power" (Marx, 1867 [1954, p.77]).

The example on the patriarchal industries of a peasant family concerns directly associated labour. In this regard, it overlaps the example on freely associated individuals, the main difference being that in the latter value is also used for the purpose of wealth distribution.

The different kinds of labour..., which result in the various products, are in themselves...direct social functions, because functions of the family, which, just as much as a society based on the production of commodities, possesses a spontaneously developed system of division of labour. The distribution of the work within the family, and the regulation of the labour-time of the several members, depend as well upon differences of sex and age as upon natural conditions varying with the seasons. The labourpower of each individual, by its very nature, operates in this case merely as a definite portion of the whole labour-power of the family, and therefore, the measure of the expenditure of individual labourpower by its duration, appears here by its very nature as a social character of their labour (Marx, 1867 [1954, pp. 77-78]). 
In the examples considered, the relation between the labour of these individuals and the objects of wealth that they create is direct ${ }^{9}$ and with this

“...there is no necessity for labour and its products to assume a fantastic form different from their reality...Here the particular and natural form of labour, and not, as in a society based on production of commodities, its general abstract form is the immediate social form of labour" (Marx, 1867 [1954, p. 77]).

Contrary to Marx's purpose, the foregoing argument implies that value can take forms other than the mercantile and this is because, as Marx himself points out, there is nothing historically specific about either the content or the quantitative determination of value. Thus, value is a feature of the commodity as generic as its quality of use value, is central to any economy based on effort and just expresses the relation there is between the articles of wealth and the sum total of society's labour. This in no way means that the type of labour that Marx analyses in Capital is generic but that the concept of value is not as specific as that of commodity-producing labour. Indeed, the relation between material wealth and society's labour takes an indirect, objective and autonomous form in commodity production. However, this historically specific feature of commodity production is not to be equated with the claim that value itself is specific to commodity production.

If the commodity is characterised as the unity-in-difference of use value and value, its specificity as a historical form of the social product collapses to the fact that it has exchange value, that is, to the form of value itself. This undermines Marx's (1867) argument since, as Levín (1997) points out, no specific form can be necessarily derived from a generic content, the same way as the physiognomy of apes cannot be necessarily derived from the concept of mammal. ${ }^{10}$ Moreover, Marx's theory of the form of value as outlined in section 3 of chapter 1 of Capital cannot account for either short run prices, which tend to differ from the long run equilibrium counterparts, or the price of irreproducible commodities, which have no value. Marx acknowledges the existence of the above deviations and highlights the former as a necessary feature of an atomistic system of production. 
Magnitude of value expresses a relation of social production, it expresses the connection that necessarily exists between a certain article and the portion of the total labour-time of society required to produce it. As soon as magnitude of value is converted into price, the above necessary relation takes the shape of a more or less accidental exchange-ratio between a single commodity and another, the money-commodity. But this exchange-ratio may express either the real magnitude of that commodity's value, or the quantity of gold deviating from that value, for which, according to circumstances, it may be parted with. The possibility, therefore, of quantitative incongruity between price and magnitude of value, or the deviation of the former from the latter, is inherent in the priceform itself. This is no defect, but, on the contrary, admirably adapts the price-form to a mode of production whose inherent laws impose themselves only as the means of apparently lawless irregularities that compensate one another (Marx, 1867 [1954, p. 102]). ${ }^{11}$

Nevertheless, he cannot consistently integrate this observation into his theory of the form of value. The form of value is presented as the necessary form of appearance of value and value represents the quantity of labour socially necessary to reproduce a commodity, which is independent of market fluctuations. Besides, not all commodities traded in the market are reproducible.

\section{The Mercantile Form of Value}

In agreement with Levín (1997), this paper proposes that the key to completing the historical characterisation of the commodity is the development of the interplay between a commodity's market value and its value in their co-constitution. In Smith's (1776) terminology, this would be the interplay between the quantity of labour a commodity commands through its exchange in the market and that contained in it. ${ }^{12}$

In order to explain how work carried out privately and independently gains an objective existence as social labour, we have to understand the most basic issue concerning commodity exchange. Marx (1867) stated this issue superbly in chapter II of Capital. 
Every owner of a commodity wishes to part with it in exchange only for those commodities whose use-value satisfies some want of his. Looked at in this way, exchange is for him simply a private transaction. On the other hand, he desires to realise the value of his commodity, to convert it into any other suitable commodity of equal [market] value irrespective of whether his own commodity has or has not any use-value for the owner of the other. From this point of view, exchange is for him a social transaction of a general character. But one and the same set of transactions cannot be simultaneously for all owners of commodities both exclusively private and exclusively social and general (Marx, 1867 [1954, pp. 85-86]).

The solution to the above contradiction provides the key to understanding how material production becomes socially recognised in an atomistic system of production, and is the first step towards understanding the origin and the nature of money. At this level of abstraction the owner of a commodity wishing to exchange it for other commodities which satisfy some want of theirs can do nothing but quote a "price" or prospective exchange value for their own commodity in terms of another commodity differing in kind. ${ }^{13}$ In so doing, the commodity producer gives rise to the simplest commodity relation: the accidental relation of exchange of one commodity for some particular other, which Marx calls the elementary or accidental form of value. Thus, contrary to Marx's claim, it is not the value relation between two commodities that originates the elementary form of value but the form that the social validation of the commodity producer necessarily takes. ${ }^{14}$ However, he rightly argues, "The whole mystery of the form of value lies hidden in this elementary form" (Marx, 1867 [1954, p. 48]).

\subsection{The Elementary or Accidental Form of Value}

$x$ commodity $\mathrm{A}=y$ commodity $\mathrm{B}$ or, equivalently, $x$ commodity $\mathrm{A}$ is worth $y$ commodity $\mathrm{B}$. In Marx's (1867 [1954, p. 48]) example, 20 yards of linen are worth 1 coat. As he points out, the two commodities play two different roles, which are mutually dependent and inseparable but which at the same time are mutually exclusive and polar opposites. The linen plays an active role, expressing 
its value in the coat, while the coat takes a passive part, serving as the material in which the value of the linen is expressed. The value of the linen, then, appears in relative form, namely relative to the coat, while that of the coat appears in equivalent form, i.e. 1 coat is made the equivalent of 20 yards of linen.

Contrary to appearance, the two distinct roles befalling either commodity are not a product of the whim of the author but the elementary form of value looked at merely as an exchange value relation does not disclose its nature. It could just as well be read the other way around and then we would say that the coat plays the relative role while the 20 yards of linen are allocated the part of equivalent. However, the elementary form of value arises necessarily from the two-fold character of commodity exchange (private and social), which stems directly from the two-fold character of commodity production. It is actually through the private and independent linen producer quoting the worth of their 20 yards of linen to be 1 coat that the 20 yards of linen acquire their relative form. The value of the 20 yards of linen is given existence relative to the coat. It is also this act that provides the coat with its equivalent form. By equating the 20 yards of linen to the coat, the coat is made directly exchangeable with the 20 yards of linen.

The way commodity producers are forced to establish the general relation of production mutates the nature of the commodity relation right from the outset. Commodity exchange is a conditional fleeting relation between two equal free wills, who are indifferent and strangers to each other. The relation is conditional because a commodity is always on offer and it is fleeting because it takes place only through the act of exchange. However, from the moment that a commodity goes on offer, the commodity in which the first one expresses its value becomes, by that very act, unconditionally exchangeable. Thus, commodity exchange turns into a relation between two unequal wills. In our example exchange is conditional for the owner of the 20 yards of linen but not for the owner of the coat; the coat owner decides whether they accept the offer or not and in so doing, they determine the course of exchange. 
Therefore, the equality implied in an exchange value relation is misleading. It is an equality ex-post, that is, if the exchange of commodities is actually carried out. However, focussing on the ex-post result makes us lose sight of the fact that the two commodities brought into relation are not equal: whereas one is unconditionally exchangeable, the other is not. If exchange takes place, the fact that 20 yards of linen are worth 1 coat undoubtedly means that 1 coat is worth 20 yards of linen, as Marx points out. However, 1 coat being worth 20 yards of linen does not imply ex-ante a reversal of the original equation but a completely new exchange relation arising from a new accidental expression of value or, in other words, from a new accidental relation of production. The new relation makes the exchange of the 20 yards of linen unconditional and that of the coat conditional. This is not just a technical subtlety, since understanding the form of value and the origin of money depends on grasping the polarity of the form of commodity exchange, for which the issue of the realisation of the commodity is central.

In Marx's understanding, in order to discover the elementary expression of value in the simplest form of commodity relation, we have to analyse the latter abstracting from its quantitative aspect. However, by not working out its most basic quantitative determination simultaneously Marx prevents himself from fully developing the specificity of the commodity. This gives rise to the fallacy that the dialectic of the form of value unfolds into the interplay between the magnitude of value and price. Since the elementary form of value springs from the manner in which the commodity producer has to establish the general relation of production, it cannot be the plain value of commodities that the form of value expresses. In a global system of production with atomistic producers only by chance would this occur, since a commodity's value represents the quantity of labour socially necessary to replace it in the market and the determination of value by labour eludes the immediate consciousness of the private and independent commodity producer. As Levín (1997) argues, the mercantile form of value expresses the "mercantile value" of commodities, that is, it does not directly express the labour value of a commodity but its realisation value. Using Smith's (1776) terminology, the mercantile form of value directly expresses the quantity of social labour 
that a commodity commands through its exchange in the market and only indirectly the quantity contained in it.

Mercantile value is specific to commodity production. Before commodity production the products of labour did not represent any quantity of social labour other than they each contained, since production was then consciously organised. Therefore, there was no need for labour to gain an existence of its own as a materially abstract autonomous substance. ${ }^{15}$ As is implicit in Marx's (1867 [1954, p. 77]) argument, the form of value was the particular and natural form of labour (see section 3). In commodity production, in contrast, the deviation of the quantity of social labour that commodities realise through their exchange in the market from the respective quantities contained in them is what brings about the adjustment of the structure of production, ensuring the stability of the system. This adjustment is based on the unawareness of individuals that it is social labour that is being re-allocated. As Levín (1997) argues, the historically specific mercantile form of value is the form of the historically specific mercantile value of commodities. Contrary to Marx's belief, the form under consideration is not the accidental or elementary form of value but the elementary or accidental form of mercantile value.

The characterisation of the commodity developed in this section and illustrated in Figure 3 does not imply a theory in which exchange has ontological primacy in the constitution of value over the moment of material production or vice versa. ${ }^{16}$ As Arthur (2002) highlights, the capitalist system is a complex totality reproducing itself in and through its moments. In section 2 it was argued that exchange and material production are the two fundamental moments comprising commodity production and therefore, they are equally important in the constitution of value in a mercantile setting, though they serve different functions. Nor is this a Ricardian regression. On the contrary, it entails the appropriation of Ricardo's (1817) concept of value and of Smith's (1776) distinction between labour commanded and labour contained as well as their transcendence. 
In short, the value of a commodity is determined by the quantity of labour socially necessary to reproduce it. However, the labour constituting itself as value in commodity production is not just any sort of labour but labour carried out privately and independently, that is, commodity-producing labour. Furthermore, this labour has to make socially useful commodities, otherwise they would have no demand and the labour would fail to constitute itself as value. ${ }^{17}$ Because commodity production is carried out privately and independently, the adjustment of the structure of production necessarily occurs through the deviation of the mercantile value of commodities from their respective values. The latter is not defined in a naturalistic manner but is determined within the market-mediated process of production. This re-conceptualisation of value and of its mode of appearance is nothing but the proper integration of Part I of Capital I.

A number of common misunderstandings are thereby cleared up. First, it becomes evident that the discussion on whether value is constituted in material production or in exchange (Arthur, 1997; Campbell, 1993; Mohun, 1994; Moseley, 1993a; Reuten, 1993) is set on wrong terms, since the value of commodities unfolds into realised value and contained value. In other words, the discussion about whether the quantity of socially necessary labour is technically or market determined refers to two different moments of the concept of commodity value. Whereas the former relates to the value of the commodity, albeit in a defective way, the latter concerns its mercantile value. Campbell (1997) captures this unsatisfactorily in terms of commodities having both an internal and an external value. Second, this section puts an end to the confusion between the quantitative determination of value and its measure (Arthur, 1993; Eldred \& Hanlon, 1981; Foley, 2005; Nelson, 2005; Reuten, 2005), which highlights the absurdity of Reuten's (2005) distinction between an introversive and an extroversive measure of value. Finally, it locates the false statement that value cannot exist without money (Arthur, 2002, 2005, 2006; Campbell, 2005; Murray, 2005; Reuten, 2005) in the incomplete historical characterisation of the commodity. 


\subsubsection{The Relative Form of Mercantile Value and Its Inseparable Connection with the Equivalent Form}

Considered as mercantile values in themselves, we reduce commodities to the abstraction that they represent mere congelations of homogeneous social labour. This substance, however, has no form of existence. In the relation between two commodities, in contrast, "the one stands forth in its character of [mercantile] value by reason of its relation to the other" (Marx, 1867 [1954, p. 50]). The relative character of the 20 yards of linen stands out in that they express their mercantile value by making the coat their equivalent. In the position of equivalent "the coat ranks qualitatively as the equal of the linen, as something of the same kind, because it is [mercantile] value" (Marx, 1867 [1954, p. 54]), that is, because it is the objective form, nay more, the bodily form of appearance of social labour. However, the coat itself is a mere use value and as such it no more tells us that it is a mercantile value than do the 20 yards of linen. When put in a relation of exchange with the linen, the coat signifies more than out of the relation. The equation 20 yards of linen $=20$ yards of linen merely says that 20 yards of linen are a definite quantity of the article linen (Marx, 1867). ${ }^{18}$

The reduction of the many sorts of materially concrete labour to homogeneous materially abstract labour is pre-supposed within the mercantile form of value itself. The linen and the coat are the products of two qualitatively different types of work. Nevertheless, by making the coat the equivalent of the linen, tailoring is equated to weaving. As regards the social character of labour, however, the process is the mirror image: the realisation of exchange turns weaving from potential or abstract social labour into actual or concrete social labour.

Private and independent work is abstract labour from a social standpoint; it is only potential social labour. The market will decide whether a certain type of private and independent work is effectively part of the social labour or if it has made a useless commodity. If the commodity is realised, so is the labour that made it, becoming socially concrete or recognised labour. Thus, it is the struggle of private and independent work to become concrete social labour that gives rise to the mercantile 
form of value and therefore reduces the materially concrete and qualitatively different types of labour to homogenous materially abstract labour.

\subsubsection{The Enigmatical Character of the Equivalent Form of Mercantile Value}

As Marx (1867) argues, the commodity allocated the role of equivalent in a relation of exchange between two commodities manifests its quality of having mercantile value by the fact that, without assuming any value form other than its bodily form, it is equated to and therefore directly exchangeable with the relative commodity. This has, according to Marx, misled many economists into seeing merely a quantitative relation in the expression of mercantile value.

The bodily form of the commodity becomes its value-form. But mark well, that this quid pro quo exists in the case of any commodity B, only when some other commodity A enters into a valuerelation [an exchange relation proper] with it, and then only within the limits of this relation. Since no commodity can stand in the relation of equivalent to itself, and thus turn its own bodily shape into the expression of its own [mercantile] value, every commodity is compelled to choose some other commodity for its equivalent, and to accept the use-value, that is to say, the bodily shape of that other commodity as the form of its own [mercantile] value (Marx, 1867 [1954, p. 56]).

The fact that no commodity can express its mercantile value in itself is but the outcome of a global mode of production where material production is carried out privately and independently. Every producer has to realise their commodity, i.e. to have it acknowledged as part of the social product, in order to acquire other commodities or, equivalently, every commodity is in principle a relative commodity. However, if a commodity was accidentally put in the position of equivalent, it would be mercantile value in its immediacy and the work of its producer directly social in character. ${ }^{19}$ Consequently, one of the peculiarities of the equivalent form of mercantile value is that "the labour of private individuals takes the form of its opposite, labour directly social in its form" (Marx, 1867 [1954, p. 59]). By the same token, materially concrete labour "becomes the form under which its opposite, [materially] abstract human labour, manifests itself" (Marx, 1867 [1954, p. 58]). In this 
case it is realised labour, as opposed to contained labour, since the concept of mercantile value concerns the conditions of realisation of commodities (Levín, 1997). Thus, the mercantile form of value boils down to the dialectic of the commodity as a useful natural article and as the objective bearer of the social relations of production, as illustrated in Figure 4.

\subsubsection{Defects of the Elementary Form of Mercantile Value}

When the commodity 20 yards of linen expresses its mercantile value in the body of the commodity coat, it merely distinguishes its mercantile value from its own bodily form. By accidentally expressing its equality with the coat the commodity 20 yards of linen is far from expressing its qualitative equality with and quantitative proportionality to all other commodities. Something similar applies to the equivalent commodity. The coat is directly exchangeable with only one commodity: the 20 yards of linen. This represents a serious deficiency in a system of production which operates on a global scale. ${ }^{20}$

Every commodity producer has to make use values for others, that is, social use values. However, in commodity production to make a social use value means to make a use value for some other random private and independent producer facing the same problem as any other. They want to realise the mercantile value of their commodity in those commodities whose use value satisfies some want of theirs, the realisation of their own commodity being an objective requirement for them to acquire other commodities. The implication of the elementary form of mercantile value is that the two-fold character of commodity exchange has to be met simultaneously by both producers brought into relation and over the same two commodities exchanged, hardly allowing the distinction between the private and the general social character of commodity exchange. Marx therefore argues that the accidental relation of exchange between two random commodities is the primitive form under which the products of labour appeared historically as commodities. 
The basic contradiction of commodity production, directly manifested in the contradiction of exchange, requires that the range of equivalent commodities - all of them particular equivalents to some extent - narrow down to one to find a mode of existence, and this brings about the general form of mercantile value. Contrary to Marx's belief, there is no logical stage of a total or expanded form of mercantile value leading to the general form (see section 4.4).

\subsection{The General Form of Mercantile Value}

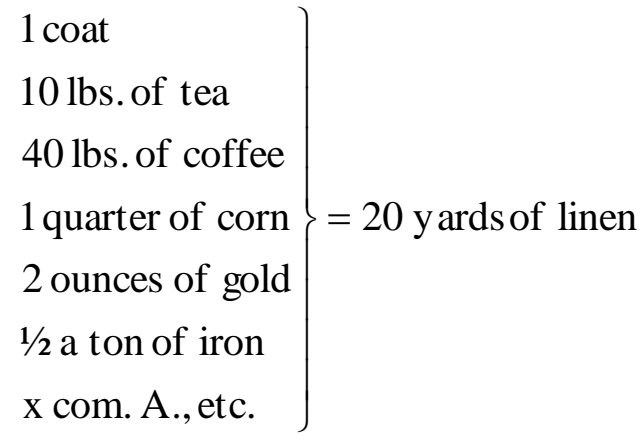

All commodities now express their [mercantile] value (1) in an elementary form, because in a single commodity; (2) with unity, because in one and the same commodity. This form of [mercantile] value is elementary and the same for all, therefore general (Marx, 1867 [1954, p. 65]).

In the example under consideration the commodity set apart as the general equivalent is the linen. However, it has not been set apart exogenously but by the very nature of the mercantile form of value. As Marx highlights, every commodity needs to find an expression of its own mercantile value and therefore seeks another commodity, which it forces into the passive role of equivalent. Thus, the general form of mercantile value arises from the joint action of all commodities. ${ }^{21}$

\subsubsection{Implications of the General Form of Mercantile Value}

In the general form of mercantile value the two poles of commodity exchange become fixed and all commodities are thereby brought into relation. Consequently, commodities "now appear not only as qualitatively equal as [mercantile] values generally, but also as [mercantile] values whose 
magnitudes are capable of comparison" (Marx, 1867 [1954, p. 66]); that is, commodities effectively appear as exchange values for the first time. ${ }^{22}$ Moreover, their social facet appears now in its positive aspect. The general form of mercantile value distinguishes the social facet of a commodity not only from its own natural body but also from the natural body of every other commodity.

As Marx points out, the equivalent commodity becomes directly exchangeable with every other commodity because its bodily form is the form that the mercantile value of every other commodity takes. In other words, every commodity producer quotes the "price" of their commodity in terms of the general equivalent. ${ }^{23}$ This turns the equivalent commodity into production straightaway and in the particular case of its process of production the distinction between the private material sphere and the social or relational moment vanishes. As a result, the producers of the equivalent commodity do not need to quote any "price" for it; they can just exchange it for the commodities they desire. In the example considered the substance linen becomes the "social chrysalis state" (Marx, 1867 [1954, p. 67]) of socially concrete labour, and hence of homogeneous materially abstract labour. This makes weaving - a particular type of labour carried out privately and independently - acquire a social character as the manifestation of realised labour in general. However, it must not be understood that, linen being directly exchangeable, it is now more convenient to produce linen than it was before. The mercantile value of linen is determined by the conditions of demand and supply and its value by its market-mediated conditions of reproduction, just like the mercantile value and the value of every other commodity.

The general form of mercantile value is the first form relating all of the different particular types of labour. ${ }^{24}$ It therefore arises from and gives expression to the establishment of social labour as an objectified autonomous substance regulating the adjustment of the structure of production. In other words, the general form of mercantile value is Smith's (1776) invisible hand, since it enables the imbalances of production to acquire an objective existence and the correction process to be triggered. It does so by making all commodities commensurable, so that their relative mercantile 
values can be compared. When the system is not in equilibrium, these will differ from the commodities' relative values and a re-specialisation process will start. ${ }^{25}$

The two-fold character of commodity exchange, in turn, takes an external form of existence, either facet becoming a distinct act. In order to acquire the commodities they desire, commodity producers must first turn their own commodities into the general equivalent. ${ }^{26}$ The reason is that the realisation of their own commodities is the only way for producers to procure themselves income or, accurately speaking, a general and unconditional means of exchange. Therefore, the fulfilment of the social side of commodity exchange comes before that of its private side, taking the form of a pre-requisite, and exchange splits into sale and purchase. Commodity producers have to sell in order to be able to buy. For the same reason, the double-coincidence of wants between two commodity producers is not needed anymore, rendering commodity production the first global mode of production. ${ }^{27}$

\subsection{The Money Form of Mercantile Value}

Marx argues that unlike the transition from the elementary to the general form of mercantile value, the transition from the latter to the money form is straightforward.

The universal equivalent form is a form of [mercantile] value in general. It can, therefore, be assumed by any commodity. On the other hand, if a commodity be found to have assumed the universal equivalent form..., this is only because and in so far as it has been excluded from the rest of all other commodities as their equivalent, and that by their own act. And from the moment that this exclusion becomes finally restricted to one particular commodity, and from that moment only, the general form of relative [mercantile] value of the world of commodities obtains real consistence and general social validity.

The particular commodity, with whose bodily form the equivalent form is thus socially identified, now becomes the money commodity, or serves as money. It becomes the special social function of that 
commodity, and consequently its social monopoly, to play within the world of commodities the part of universal equivalent (Marx, 1867 [1954, p.69]). ${ }^{28}$

The only difference between the general form of mercantile value and the money form is that the role of general equivalent becomes the monopoly of one particular commodity: in Marx's scheme, gold. If gold becomes money, it is because it was previously just another simple commodity, in principle as suitable as any other to serve as an equivalent. The elementary expression of the mercantile value of a simple commodity in terms of the money commodity, in turn, gives rise to the price form. In Marx's example, the 20 yards of linen are now worth 2 ounces of gold. Assuming that 2 ounces of gold when coined are $£ 2,20$ yards of linen are worth $£ 2$, presenting the price form in terms of a standard of prices.

When the previous sections noted that a commodity producer has to quote a price for their commodity, this was, accurately speaking, wrong; this is why the word price appeared between inverted commas. Price is the expression of a commodity's mercantile value in money form. It means that the commodity's mercantile value is expressed in the equivalent form socially consecrated, putting the commodity in question on an equal footing with all others. In the elementary form of mercantile value a commodity producer actually quotes a prospective mercantile or realisation value for their commodity in terms of a particular equivalent, namely a commodity which outside this accidental exchange relation is just another relative commodity. However, only the degree of development of the form of mercantile value distinguishes the general from the particular equivalent, since both arise from the same process: the mechanism of realisation of commodities as part of the social product. As Marx argues, quoting Aristotle, "5 beds = 1 house is not to be distinguished from 5 beds = so much money" (Marx, 1867 [1954, p. 59]).

The key to understanding the concept of money lies in grasping the universal equivalent form of commodities and the general form of mercantile value. The differentiation between a relative and an equivalent commodity is already present in the elementary form of mercantile value and necessarily 
springs from the manner in which commodity producers are forced to establish the general relation of production. Thus, the elementary form of mercantile value is the germ of the money form. It is now evident that the process giving rise to money and the process of realisation of commodities as part of the social product are one and the same.

A commodity is not just the unity-in-difference of use value and value. A commodity is a use value (an object of utility as a means of consumption or production) and a mercantile use value (an object of utility as a means of exchange). ${ }^{29} \mathrm{~A}$ commodity is also a value (the embodiment of the social labour necessary to reproduce it) and a mercantile value (the embodiment of command over social labour). However, it manifests its multifaceted and contradictory nature only when its mercantile value takes an independent form, i.e. the form of exchange value, never in isolation; hence the fundamental importance of understanding the mercantile form of value.

The analysis of this form shows the necessary interplay between the objective and the subjective moments of commodity production. A commodity expresses its mercantile value in the body of a different commodity, that is, in the form of exchange value. The ratio of its mercantile value to that of all other commodities, in turn, determines its mercantile use value. The interplay between the mercantile use value and the use value of commodities governs the individual behaviour of commodity producers, since it determines which commodities they will supply and which they will demand as well as in what amounts. However, the behaviour of all commodity producers taken together feeds back on the mercantile values of the different commodities. The individual behaviour of commodity producers as the unity-in-difference of "homo-mercator" and "homo-laborans" (Levín, 1997) ${ }^{30}$ causes both the role of the market to be exclusively the allocation of social labour and the mercantile values of commodities to converge, ceteris paribus, on their values.

Thus, value does not assert itself directly in the equivalent commodity but indirectly through the adjustment of the structure of production. As Marx (1867) argues, a form of value directly 
expressing value would be an oxymoron in an atomistic and global system of production. Since the notion of value as the substantiation of social labour is necessarily absent from the immediate consciousness of commodity producers, such a form of expression of value would render the system unstable, preventing its adjustment. ${ }^{31}$

In addition, Marx's theory of money explains why money was originally a commodity, and necessarily is one at the abstract theoretical level of the commodity (Campbell, 2005; Foley, 2005; Germer, 2005). However, it is not the theory of a money commodity (Ahumada, 2009; Arthur, 2005, 2006; Bellofiore, 2005; Campbell, 1997, 2005; Eldred \& Hanlon, 1981; Lapavitsas, 2005; Levín, 1997; Reuten, 2005). As follows from section 4, the role of universal equivalent is unrelated to the natural characteristics of commodities. In effect, the use value of the equivalent commodity, i.e. its usefulness as a natural object, is completely irrelevant when it plays the role of universal equivalent; as far as usefulness is concerned, the only thing that matters is that it is a mercantile use value. $^{32}$ Therefore, there is no reason why the measure of mercantile value should not be fiat money or a Wicksellian abstract unit of account but in order to elucidate the conditions of appearance of credit money, it is necessary to develop a satisfactory theory of capital.

\subsection{Critique of the Total or Expanded Form of Mercantile Value}

Only a developed money form of mercantile value allows putting the mercantile value of a commodity in terms of a chain of other commodities. This occurs because all commodities express their mercantile values in the same commodity. The chain, however, is merely the reflection of the commensurability of all commodities once the money form has been established or, equivalently, the external form of appearance that from a social viewpoint commodities are nothing but the representation of social labour. Contrary to Marx's belief, this is no expression of mercantile value but merely a chain of relative prices and therefore it cannot be the conceptual link between the elementary and the general form of mercantile value. 
According to Marx, the isolated or accidental expression of a commodity's mercantile value is convertible into a series of expressions where all the commodities which the first one is compared with play the role of particular equivalents. A fragmentary equivalent form, however, is not directly exchangeable and consequently contradicts the essential feature of the equivalent form of mercantile value. In effect, if the commodity 20 yards of linen expresses its mercantile value in an assorted range of commodities, it means that these "equivalents" compete with one another, losing the quality of being directly exchangeable and thus the incarnation of mercantile value. In fact, it is the 20 yards of linen that are the equivalent commodity; the rest are just relative commodities, the converse of what he claims it to be. Consequently, Marx's expanded form of mercantile value is already the general form of mercantile value, albeit wrongly conceptualised. ${ }^{33}$

\section{Why Does Society's Labour Take the Form of Reified Abstract Labour? Why Is It Allocated Under the Form of an Autonomous Allocation of Objects?}

Ahumada (2009) provides a key insight; it reminds us that commodity production is nothing but the organisation of the labour of society for the reproduction of its material conditions of existence, just like any other form of production. This is the generic aspect of commodity production. The present paper has shown that in commodity production society's labour takes not only an immediate material form in the body of commodities but also an autonomous materially abstract social form which finds its necessary developed expression in the money form of commodities, thereby regulating the adjustment of the system of production. This is the historically specific aspect of commodity production. Consequently, the allocation of society's labour occurs under the guise of an autonomous allocation of objects, which Marx (1867) refers to as the fetishism of commodities. We now need to understand why society's labour takes an autonomous materially abstract form and why it expresses itself in such a convoluted way if we are to comprehend commodity production. This is the key to solving the so-called transformation problem and properly conceptualising crucial issues such as sustainability and monetary phenomena. 
The fact that commodity production is atomistic and operates on a global scale means that commodity producers are free and independent individuals. Thus, nobody can make them apply their productive powers in any particular way. Moreover, their atomistic behaviour prevents any conscious form of organisation of society. Then, how can production take place at all? How can the labour of society be organised? Money both poses the riddle and offers the solution. Commodity production organises society's labour through its recognition (or not) as social labour in the transformation of commodities into money. ${ }^{34}$

Therefore, it is not its value that a commodity directly expresses in its exchange in the market but its mercantile value. The mercantile form of value is the roundabout way for commodity production to organise society's labour, since it is what allows a commodity to command a different amount of social labour than it contains. The deviation of the mercantile values of commodities from their respective values, which are themselves market mediated, implies different degrees of recognition of the labour of private and independent individuals in the conversion of their commodities into money. This triggers the adjustment of the structure of production or, in other words, the reallocation of the labour of society in the way that best satisfies its historically specific and formdetermined material wants and needs given the natural conditions in which its labour power is applied. The subjective side of the process operates exclusively through the dialectic of the commodity as a use value and as a mercantile use value. The objective outcome of the system, in turn, comes about through the commodity's dialectic as a value and as a mercantile value, though this escapes the immediate consciousness of individuals. Thus, the mercantile form of value is what endows society's labour with its autonomous and materially abstract character and what makes this substance elude the perception of individuals.

Mercantile value is equal to value on aggregate for the simple reason that the quantity of useful labour realised through the process of reproduction of the material conditions of existence of society cannot differ from the quantity of useful labour exerted for it. This is therefore an identity. ${ }^{35}$ In 
direct pre-capitalist forms of production the quantity of social labour that an individual product represented was identical to the quantity contained in it. In other words, there was no need for an autonomous representation of value; the form of value was the natural form of the product. Because commodity production is indirect, these quantities of labour have to differ a priori. Nevertheless, if the system of production is to be stable, in the long run mercantile value has to be equal to value on an individual commodity basis at the abstract theoretical level of the commodity.

Even if one comes to understand that society's labour takes an autonomous materially abstract form, one may still wonder why it takes such a convoluted way of expressing itself, with, as Backhaus (1980) puts it, the abstract and general expressing itself in a concrete particular. If the price system allocates nothing but quantities of social labour, why are commodities exchanged for money instead of labour vouchers? Marx scorned this type of reasoning. Commodity production cannot be organised on either a conscious or a directly coercive basis. Nonetheless, producers have to discover somehow what materially concrete way they should apply their productive powers, otherwise the system would be unstable and society would collapse. The system offers signals in the form of relative prices, which provide material incentives for individuals to engage in certain productive activities. Turning commodities into labour vouchers would imply that labour is directly social and therefore some form of conscious organisation of production, which would contradict the very foundation of commodity production.

Once the mercantile form of value has developed into its money form, it becomes autonomous. That is, value - the trans-historical mediating link between the pursuit of use value and the allocation of labour - takes on its historically specific role as the objective mediator of the process of production, thereby becoming, in Postone's (1993) terms, the social form of wealth. ${ }^{36}$ The shoemaker will quote the price of their shoes in money regardless of whether they have made the shoes themselves, or if there has been an army of elves working freely for the shoemaker at night, or if the shoes have landed from heaven. ${ }^{37}$ The same would be the case for the seller of an irreproducible or an 
imperfectly reproducible commodity. ${ }^{38}$ The indirect way that the general relation of production is established in commodity production erases all traces of social labour and inherently allows not only short run but also long run deviations of the mercantile value of commodities from their respective values. Owing to the atomistic and global character of commodity production every object of utility has to command a price or, equivalently, have mercantile value irrespective of whether it has value, that is, whether it is reproducible, and how it was obtained. ${ }^{39}$

The long run equilibrium mercantile values of commodities differ from their respective values not only when there is exchange of irreproducible commodities but also when in the process of production of the different commodities the role of homo-mercator and that of homo-laborans are each played by a different actor. The money form of commodities allows the accumulation of realised social labour in a general form and with this, the accumulation of general command over social labour and its observable counterpart, purchasing power, thus spawning the most general form of capital. With the appearance of undifferentiated capital the tendency towards the equalisation of the rate of profit of the different concrete capitals becomes the over-riding force regulating the adjustment of the structure of production. Therefore, the equilibrium relative prices no longer accurately reflect the conditions of reproduction of commodities. Furthermore, the possibility of accumulation of purchasing power replaces the satiation of needs and wants with frenzy for profit as the driver of production, a process with no concrete end in itself, posing the threat of production taking place at an unsustainable pace and magnitude.

\section{Conclusion}

The process through which material production becomes socially recognised in commodity production and the process giving rise to money are the same, and they are only the material manifestation of the process of realisation of private and independent work as social labour. Money both proposes the riddle and provides the solution: private and independent work becomes social labour through its product being turned into a certain amount of money. 
The explanation offered in this paper differs from Marx's (1867) in that it breaks the false dichotomy between the objective and the subjective approaches to the theory of the commodity and firmly establishes the fundamental concept of mercantile form of value. This characterises the commodity as the unity-in-difference of value and mercantile value, the former representing the quantity of labour socially necessary to reproduce the commodity and the latter the quantity of social labour that it commands through its exchange in the market. As a result, this re-interpretation of Marx's theory of the commodity offers a consistent account of the origin of money and breaks the false immediate links between supply and production, between means of production and capital, and between money and capital.

The appearance of money is implicit in the most elementary relation of commodity production: the accidental exchange relation between two particular commodities. Once a commodity producer has made a prospective article of utility, they can do nothing but quote a "price" for it in the form of a commodity differing in kind. This way of relating contains the germ of money. The first commodity takes the relative form of mercantile value, since it expresses its mercantile value relative to the second commodity. As a result, the second commodity is made the equivalent of the first one, or unconditionally exchangeable with it. Thus, within this exchange relation the second commodity becomes the visible incarnation of realised production or, equivalently, of socially concrete, though materially abstract, labour.

Since commodity production operates on a global scale, the elementary form of mercantile value is defective. It lacks unity and barely distinguishes the social from the private side of commodity exchange. The contradictory nature of commodity production as a private and a general social act necessarily brings about the general form of mercantile value, in which the equivalent form of mercantile value is allocated to a single commodity set aside by all others, and which as a result makes all commodities commensurable. Once the role of general equivalent is exclusively allocated 
to one commodity in particular, this commodity becomes money and commodity production as a global mode of production emerges as an objective reality.

The money commodity is the socially consecrated denominator of the mercantile value of every other commodity. Consequently, in the right quantity the money commodity is directly exchangeable with all others; that is, money is the general form of appearance of social labour or, equivalently, of realised production and is therefore purchasing power. As a result, the two-fold character of commodity exchange gains an external form of existence: sale and purchase. The social facet turns into the requirement that commodities be converted into money, since this is the proof that the material process that made them was indeed production. Once they have been sold, or realised, the fulfilment of the private facet of commodity exchange (the satisfaction of a want or need through the purchase of some other commodities) is just a matter of course. The quantity of money that a commodity is turned into determines the degree of recognition that a certain type of labour gets, triggering re-specialisations until the required structure of production results. When this happens, commodities are exchanged at their values. However, the possibility of permanent quantitative incongruity between the mercantile values of commodities and their respective values is pre-supposed within the mercantile form of value itself, although on aggregate the former is always identical to the latter. This lays out the groundwork for re-conceptualising and solving the so-called transformation problem.

Finally, to reduce Marx's concept of money to merely a money commodity reveals a serious misreading of Marx and especially a misunderstanding of the mercantile form of value. As Marx argues, gold was the money commodity not because it was gold but because it was the incarnation of the equivalent form of mercantile value. That is, the use value of the equivalent commodity, namely its usefulness as a natural object, is irrelevant when it plays the role of universal equivalent; in regard to usefulness, only its quality of mercantile use value counts. Nevertheless, accounting for the appearance of credit money requires a satisfactory theory of capital. 


\section{Endnotes}

1 E.g. Bandyopadhyay (1984-1985), Baumol (1974a, 1974b), Böhm-Bawerk (1896), Bortkiewicz (1907), Carling (1984-1985), Hilferding (1904), Laibman (1984-1985), Meek (1956, 1976), Morishima (1974), Morishima \& Catephores (1975, 1976), Morishima \& Seton (1961), Samuelson (1970, 1971, 1973, 1974a, 1974b, 1982), Seton (1957), Sraffa (1960), Steedman (1977) and Winternitz (1948).

${ }^{2}$ See Arthur (1997, 2002, 2004, 2006), Campbell (1997), Duménil (1984), Eldred \& Hanlon (1981), Lysandrou (2000), Mohun (1984-1985, 1994), Moseley (1993b, 2005) and Postone (1993).

${ }^{3}$ E.g. Bortkiewicz (1907), Morishima \& Seton (1961), Roemer (1980), Seton (1957), Sraffa (1960), Steedman (1977) and Winternitz (1948).

${ }^{4}$ E.g. Arthur (2002, 2005), Backhaus (1980), Campbell (1993), Eldred \& Hanlon (1981), Lapavitsas (2005), Moseley (1993a), Murray (2005) and Reuten (1993, 2005).

${ }^{5}$ Ahumada (2009) shows that the allocation of society's labour entails the allocation of all the specific material inputs to production, breaking the false association between the labour theory of value and the single-factor theory of production.

${ }^{6}$ In Marx's $(1867,1885,1894)$ view, production is a specific type of social relation entailing a material exchange with the environment. Thus, production is the union of a material and a social or relational moment.

${ }^{7}$ This tension is disregarded outright by Eldred \& Hanlon (1981) and overlooked by both Smith (1993) and Germer (2005)

${ }^{8}$ This means that, contrary to Murray's (1993) claim, Marx (1867, 1885, 1894) did not fully transcend Ricardo's (1817) concept of value.

${ }^{9}$ The reason is that the first example does not involve social relations, that in the second example the social relations of production are direct relations of personal servitude, and that in the third and fourth production is consciously organised.

${ }^{10}$ Murray (1997) expresses the same idea by arguing that a form belongs to its essence. In contrast, Arthur (1993, 2002, 2005, 2006) presents the form of value as a form, in principle, void of content, which develops itself and sinks into the sphere of production in search of its adequate content. Moseley (1993a) and Lapavitsas (2005) hold a similar view.

${ }^{11}$ The first sentence of the quote further supports this paper's argument that value is a generic concept associated with reproducible products regardless of the specific social form in which they are produced. 
12 Contrary to Murray's (1993) belief, there can be no interplay between value and price because they are incommensurable. As is apparent in section 3, the dialectic of value as the interplay between the form of value and the magnitude of value is a contradiction in terms.

${ }^{13}$ The same as with capital, within the framework of this paper the presence of money cannot be simply taken for granted. Money - a mediated concept - has to be accounted for from the development of the most basic concepts underlying commodity production.

${ }^{14}$ Since value is a generic content of commodities, it does not assert itself immediately in the form of exchange value.

${ }^{15}$ Or, as Postone (1993) puts it, as an objective socially mediating activity.

${ }^{16}$ However, this is the case in Backhaus (1980), Arthur (2005, 2006), Reuten (1993, 2005), Campbell (2005), Bellofiore (2005), Murray (2005), Carchedi (1993), Meek (1956), Sraffa (1960) and Steedman (1977).

17 " $[\mathrm{N}]$ othing can have value, without being an object of utility. If the thing is useless, so is the labour contained in it; the labour does not count as labour, and therefore creates no value” (Marx, 1867 [1954, p. 41]).

18 “A, for instance, cannot be "your majesty" to B, unless at the same time majesty in B's eyes assumes the bodily form of A, and, what is more, with every new father of the people, changes its features, hair, and many other things besides" (Marx, 1867 [1954, pp. 51-52]).

${ }^{19}$ The producer's work may not be quantitatively recognised, as the adjustment of the structure of production occurs through the deviation of the mercantile value of the different commodities from their respective values. Since the value of a commodity does not reflect past labour but the quantity of labour socially necessary to reproduce it, even in the long run a particular labour may get more than or less than full quantitative social recognition. This will occur if its expenditure in the production of a commodity is at variance with the quantity of labour socially necessary to reproduce the commodity or, in other words, if the individual value of the commodity is not equal to its value.

${ }^{20}$ Eldred \& Hanlon (1981) argue that no commodity in itself can serve in its particularity as the material for the expression of value, highlighting the defects of the elementary form of mercantile value but at the same time foreshadowing the paradoxical features of the money form of mercantile value. Germer (2005), in turn, points out that for a particular act of labour to be recognised as social labour, its product must be exchangeable for any other act of labour, not just one particular act. 
21 "A commodity can acquire a general expression of its [mercantile] value only by all other commodities, simultaneously with it, expressing their [mercantile] values in the same equivalent; and every new commodity must follow suit” (Marx, 1867 [1954, p. 66]).

22 "For instance, $10 \mathrm{lbs}$. of tea $=20$ yards of linen, and $40 \mathrm{lbs}$. of coffee $=20$ yards of linen. Therefore, $10 \mathrm{lbs}$. of tea $=$ 40 lbs. of coffee" (Marx, 1867 [1954, p. 66]).

23 "The degree of development of the relative form of [mercantile] value corresponds to that of the equivalent form. But we must bear in mind that the development of the latter is only the expression and result of the development of the former...[A] particular kind of commodity acquires the character of universal equivalent, because all other commodities make it the material in which they uniformly express their [mercantile] value” (Marx, 1867 [1954, p. 67]).

${ }^{24}$ The general form of mercantile value is actually the money form stripped of its use value disguise or, in other words, it is the theoretical step that allows us to see that the universal equivalent form of mercantile value is ultimately unrelated to the use value of commodities and can in principle be taken on by any of them.

${ }^{25}$ Both mercantile value and value are defined in absolute terms in this paper. However, as Ahumada (2009) shows, within the framework of commodity production the convergence of the mercantile values of commodities on their respective values can only be attained indirectly through the convergence of their relative mercantile values on their respective relative values.

${ }^{26}$ The exception is linen producers. They only have to fulfil the private side of commodity exchange because the social is fulfilled ex-ante.

${ }^{27}$ In light of the reconstruction of the mercantile form of value outlined in this paper, the discussion about whether offering a commodity is an offer to sell (Lapavitsas, 2005) or an offer to buy (Arthur, 2005) makes no sense at all. Prior to the emergence of the general form of mercantile value, the private and the social facet of commodity exchange are realised simultaneously over the two commodities that enter into the accidental relation of exchange. Thus, there is neither sale nor purchase. Once the general form of mercantile value has been established, it is clear that an offer is always an offer to sell, since the realisation of the offered commodity is always conditional; that is, the offered commodity can take nothing but the relative form of mercantile value.

${ }^{28}$ Campbell (2005) argues that money arises from the need of commodities to express their [mercantile] values in a single unit. This makes clear that in the process giving rise to money commodities are the prime movers, and that, contrary to Arthur's (2006) claim, the equivalent form of mercantile value is passive. 
${ }^{29}$ The term "mercantile use value" was first introduced by Levín (1997) to refer to the commodity’s utility as a means of exchange. Lapavitsas (2005) calls this historically specific form of use value "formal use value", whereas for Arthur (2005) this is just the value of the commodity. Thus, Arthur's commodity is underspecified.

${ }^{30}$ In other words, as trader of commodities in the market and as productive worker.

${ }^{31}$ The details of the system's adjustment mechanism and of the actual operation of the law of labour value are discussed in Ahumada (2009).

${ }^{32}$ As Marx (1867) highlights, the use value of money is not present in its own material shape but in that of each commodity it acquires.

${ }^{33}$ The expanded form of mercantile value is defended by Arthur (2006), Lapavitsas (2005) and Smith (1993). However, Arthur's (2006) critique of the Uno school and Lapavitsas's (2005) understanding of the universal equivalent as the monopolist of the ability to buy reveal that the expanded form is a contradiction in terms.

${ }^{34}$ In agreement with Campbell (2005), this paper implies that the primary function of money is that of measure of mercantile value, its functions as a means of circulation, as a means of payment and as a store of value stemming from its primary function.

35 The fact that aggregate mercantile value cannot be less than aggregate value implies neither adherence to Say's Law nor a state of general equilibrium. In commodity production an act of labour in its immediacy does not count as part of the social labour; it does so through the mediation of the market, i.e. value and mercantile value are co-constituted. If commodities go unsold, the labour embodied in them is wasted and does not constitute itself as either mercantile value or value, that is, it fails to become part of the social labour (see endnote 17).

${ }^{36}$ As additional support to the argument that value is specific to commodity production, Postone (1993) outlines the historical evolution of the concept of time, highlighting that the idea of abstract time, elapsing at a constant pace, measurable in homogeneous units and serving as a measure of working activity, instead of being measured by it, is an eminently capitalist phenomenon. However, as is implicit in section 3, the concept of value is as generic as the concept of time itself. Hence, it is not that just the form of appearance of value changes historically but, rather, this is the expression and result of changes in its content.

${ }^{37}$ The last two cases are examples of commodities which command social labour through their exchange in the market even though they were not made by social labour. 
${ }^{38}$ Note that the shoes in our tricky example, unlike irreproducible products, would have value regardless of how they were obtained. This is because the value of a product does not reflect the amount of labour actually expended in order to make it but the quantity of labour socially necessary to reproduce it.

${ }^{39}$ Campbell (2005) misrepresents the case of commodities possessing only mercantile value as prices which may express value that is not there. Lapavitsas (2005), in turn, wrongly claims that there are forms of value which are unconnected with the substance of value. 
Figure 1: The differentiation of production in capitalism

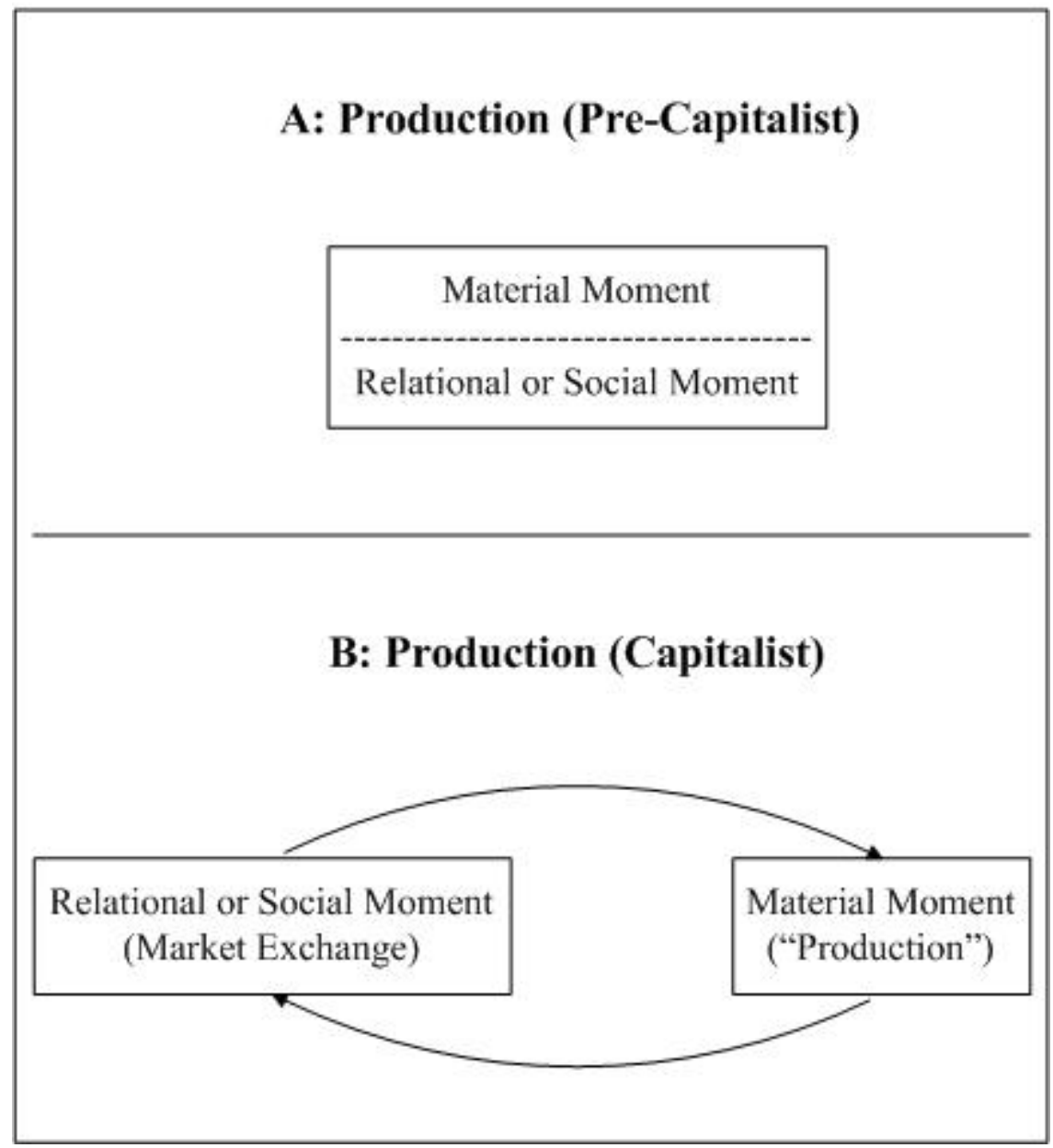


Figure 2: Marx's conceptualisation of commodity production

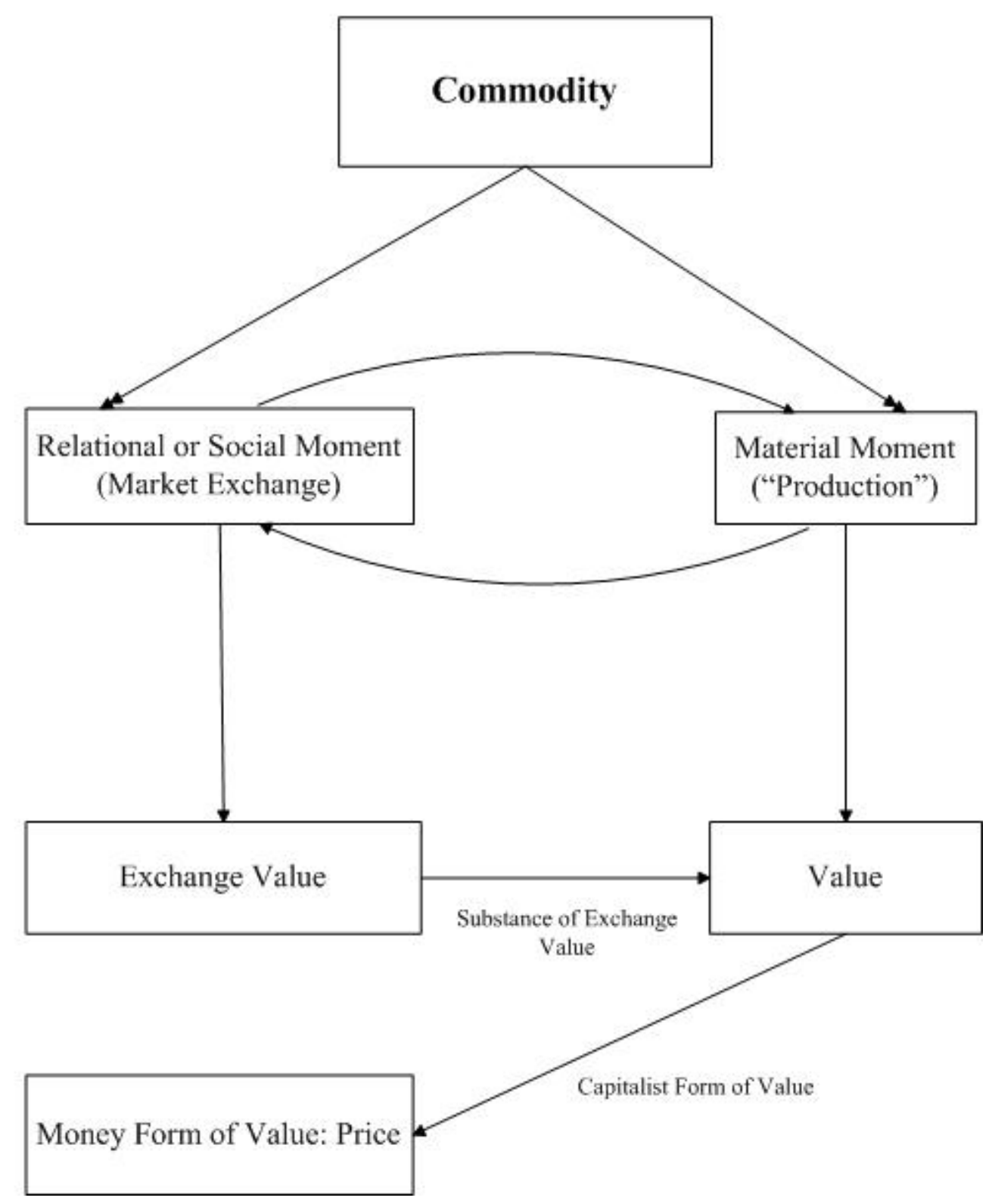


Figure 3: The objective dialectic of the commodity and its bearing on the productive structure

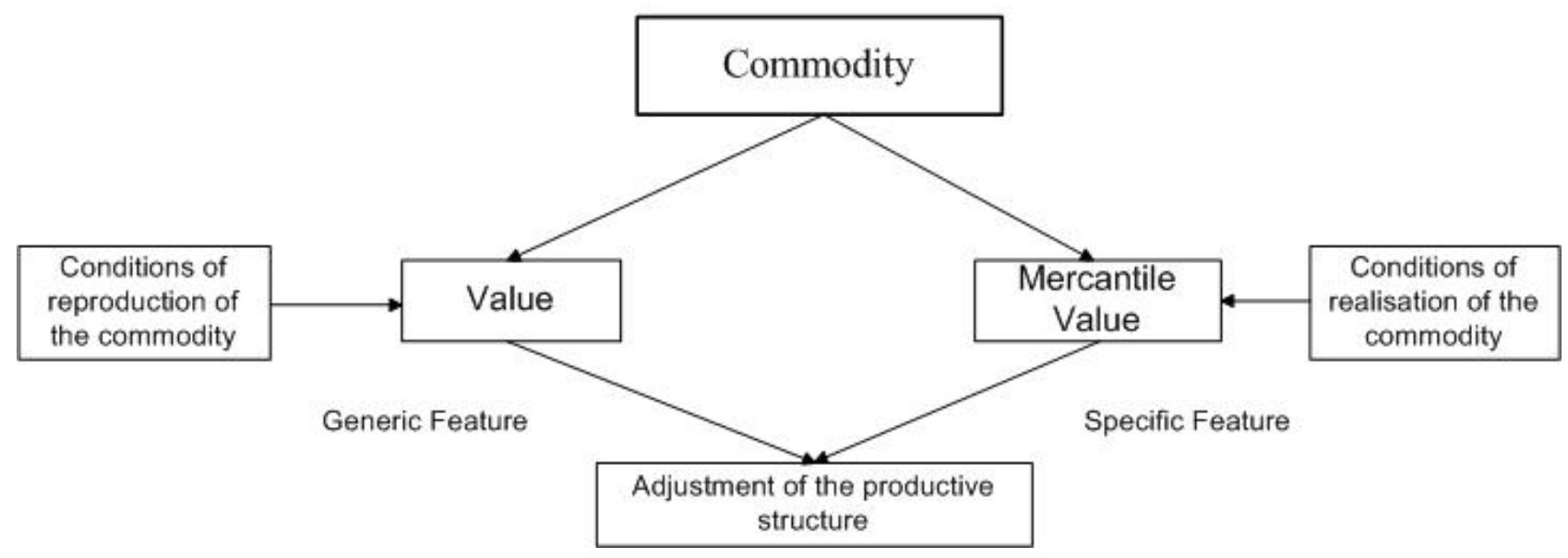

Figure 4: The general dialectic of the commodity

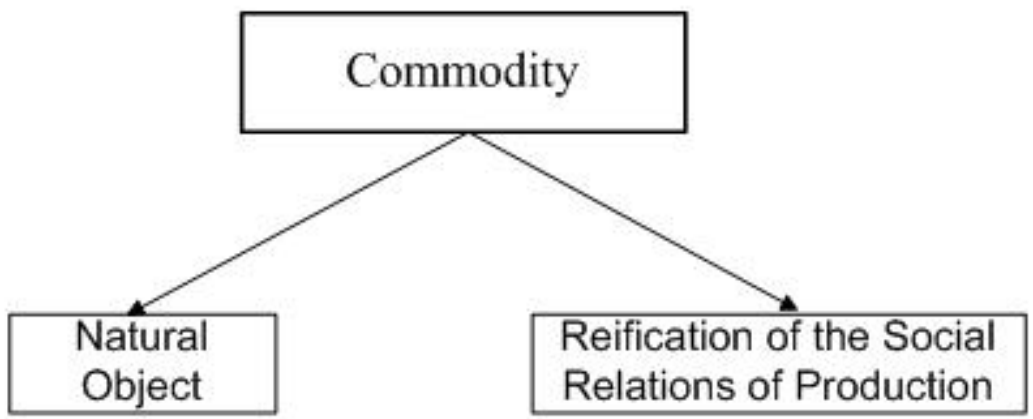

Generic Feature

Specific Feature 


\section{REFERENCES}

Ahumada, P. E. (2009). An updated Marxian theory of the commodity: An alternative key to making sense of capitalist production. Saarbrücken: VDM Verlag.

Arthur, C. J. (1993). Hegel's Logic and Marx's Capital. In F. Moseley (Ed.), Marx's method in Capital: a reexamination. New Jersey: Humanities Press.

Arthur, C. J. (1997). Against the logical-historical method: dialectical derivation versus linear logic. In F. Moseley \& M. Campbell (Eds.), New investigations of Marx's method. New Jersey: Humanities Press.

Arthur, C. J. (2002). The new dialectic and Marx's Capital. Leiden: Brill.

Arthur, C. J. (2004). Money and the form of value. In R. Bellofiore \& N. Taylor (Eds.), The constitution of Capital. Essays on Volume I of Marx's Capital. Basingstoke: Palgrave Macmillan.

Arthur, C. J. (2005). Value and money. In F. Moseley (Ed.), Marx's theory of money. Basingstoke, Hampshire: Palgrave Macmillan.

Arthur, C. J. (2006). Money and exchange. Capital and Class, 90, 7-36.

Backhaus, H.-G. (1980). On the dialectics of the value-form. Thesis Eleven, 1, 99-120.

Bandyopadhyay, P. (1984-1985). Value and post-Sraffa Marxian analysis. Science \& Society, XLVIII(4), 433-448.

Baumol, W. J. (1974a). The fundamental Marxian theorem: A reply to Samuelson: Comment. Journal of Economic Literature, 12(1), 74-75.

Baumol, W. J. (1974b). The transformation of values: What Marx "really" meant (an interpretation). Journal of Economic Literature, 12(1), 51-62.

Bellofiore, R. (2005). The monetary aspects of the capitalist process in the Marxian system: an investigation from the point of view of the theory of the monetary circuit. In F. Moseley (Ed.), Marx's theory of money. Basingstoke, Hampshire: Palgrave Macmillan. 
Böhm-Bawerk, E. v. (1896). Karl Marx and the close of his system. In P. M. Sweezy (Ed.), Karl Marx and the close of his system. New York: A.M. Kelley, 1949.

Bortkiewicz, L. v. (1907). On the correction of Marx's fundamental theoretical construction in the third volume of Capital. In P. M. Sweezy (Ed.), Karl Marx and the close of his system. New York: A. M. Kelley, 1949.

Campbell, M. (1993). Marx's concept of economic relations and the method of Capital. In F. Moseley (Ed.), Marx's method in Capital: a reexamination. New Jersey: Humanities Press.

Campbell, M. (1997). Marx's theory of money: A defense. In F. Moseley \& M. Campbell (Eds.), New investigations of Marx's method. New Jersey: Humanities Press.

Campbell, M. (2005). Marx's explanation of money's functions: overturning the quantity theory. In F. Moseley (Ed.), Marx's theory of money. Basingstoke, Hampshire: Palgrave Macmillan.

Carchedi, G. (1993). Marx's logic of enquiry and price formation. In F. Moseley (Ed.), Marx's method in Capital: a reexamination. New Jersey: Humanities Press.

Carling, A. (1984-1985). Observations on the labor theory of value. Science \& Society, XLVIII(4), 407-418.

Duménil, G. (1984). Beyond the transformation riddle: A labor theory of value. Science \& Society, XLVII(4), 427-450.

Eldred, M., \& Hanlon, M. (1981). Reconstructing value-form analysis. Capital and Class, 13, 2460.

Foley, D. K. (2005). Marx's theory of money in historical perspective. In F. Moseley (Ed.), Marx's theory of money. Basingstoke, Hampshire: Palgrave Macmillan.

Germer, C. (2005). The commodity nature of money in Marx's theory. In F. Moseley (Ed.), Marx's theory of money. Basingstoke, Hampshire: Palgrave Macmillan.

Hilferding, R. (1904). Böhm-Bawerk's criticism of Marx. In P. M. Sweezy (Ed.), Karl Marx and the close of his system. New York: A. M. Kelley, 1949. 
Kicillof, A., \& Starosta, G. (2007). On materiality and social form: a political critique of Rubin's value-form theory. Historical Materialism, 15, 9-43.

Laibman, D. (1984-1985). Value: A dialog in one act. Science \& Society, XLVIII(4), 449-465.

Lapavitsas, C. (2005). The universal equivalent as monopolist of the ability to buy. In F. Moseley (Ed.), Marx's theory of money. Basingstoke, Hampshire: Palgrave Macmillan.

Levín, P. E. (1997). El capital tecnológico. Buenos Aires: Catálogos. Universidad de Buenos Aires. Facultad de Ciencias Económicas.

Lysandrou, P. (2000). The market and exploitation in Marx's economic theory: A reinterpretation. Cambridge Journal of Economics, 24, 325-347.

Marx, K. (1857). Marx's Grundrisse (D. S. McLellan, Trans.). (Edited by D. S. McLellan). St Albans, Herts.: Paladin, 1973.

Marx, K. (1867). Capital: A critique of political economy. Volume I (S. Moore \& E. Aveling, Trans.). (Edited by F. Engels). Moscow ; London: Foreign Languages Publishing House ; Lawrence And Wishart, 1954.

Marx, K. (1885). Capital: A critique of political economy. Volume II (S. Moore \& E. Aveling, Trans.). (Edited by F. Engels). Moscow ; London: Foreign Languages Publishing House ; Lawrence And Wishart, 1954.

Marx, K. (1894). Capital: A critique of political economy. Volume III (S. Moore \& E. Aveling, Trans.). (Edited by F. Engels). Moscow ; London: Foreign Languages Publishing House ; Lawrence And Wishart, 1954.

Mattick Jr., P. (1993). Marx's dialectic. In F. Moseley (Ed.), Marx's method in Capital: a reexamination. New Jersey: Humanities Press.

Meek, R. L. (1956). Some notes on the "transformation problem". Economic Journal, 66, 94-107.

Meek, R. L. (1976). Is there an "historical transformation problem"? A comment. Economic Journal, 86, 342-347.

Mohun, S. (1984-1985). Abstract labor and its value-form. Science \& Society, XLVIII(4), 388-406. 
Mohun, S. (1994). A re(in)statement of the labour theory of value. Cambridge Journal of Economics, 18, 391-412.

Morishima, M. (1974). The fundamental Marxian theorem: A reply to Samuelson. Journal of Economic Literature, 12(1), 71-74.

Morishima, M., \& Catephores, G. (1975). Is there an "historical transformation problem"? Economic Journal, 85(1), 309-328.

Morishima, M., \& Catephores, G. (1976). The "historical transformation problem": A reply. Economic Journal, 86, 348-352.

Morishima, M., \& Seton, F. (1961). Aggregation in Leontief matrices and the labour theory of value. Econometrica, 29, 203-220.

Moseley, F. (1993a). Marx's logical method and the "transformation problem". In F. Moseley (Ed.), Marx's method in Capital: a reexamination. New Jersey: Humanities Press.

Moseley, F. (Ed.). (1993b). Marx's method in Capital: a reexamination. New Jersey: Humanities Press.

Moseley, F. (Ed.). (2005). Marx's theory of money. Basingstoke, Hampshire: Palgrave Macmillan.

Murray, P. (1993). The necessity of money: how Hegel helped Marx surpass Ricardo's theory of value. In F. Moseley (Ed.), Marx's method in Capital: a reexamination. New Jersey: Humanities Press.

Murray, P. (1997). Redoubled empiricism: the place of social form and formal causality in Marxian theory. In F. Moseley \& M. Campbell (Eds.), New investigations of Marx's method. New Jersey: Humanities Press.

Murray, P. (2005). Money as displaced social form: why value cannot be independent of price. In F. Moseley (Ed.), Marx's theory of money. Basingstoke, Hampshire: Palgrave Macmillan.

Nelson, A. (2005). Marx's objections to credit theories of money. In F. Moseley (Ed.), Marx's theory of money. Basingstoke, Hampshire: Palgrave Macmillan. 
Postone, M. (1993). Time, labor and social domination: a reinterpretation of Marx's critical theory. Cambridge: Cambridge University Press.

Reuten, G. (1993). The difficult labor of a theory of social value: metaphors and systematic dialectics at the beginning of Marx's Capital. In F. Moseley (Ed.), Marx's method in Capital: a reexamination. New Jersey: Humanities Press.

Reuten, G. (2005). Money as constituent of value. In F. Moseley (Ed.), Marx's theory of money. Basingstoke, Hampshire: Palgrave Macmillan.

Ricardo, D. (1817). On the principles of political economy and taxation. (Edited with an introduction by R. M. Hartwell). Harmondsworth: Penguin, 1971.

Roemer, J. E. (1980). A general equilibrium approach to Marxian economics. Econometrica, 48(2), 505-530.

Rosdolsky, R. (1969). The making of Marx's 'Capital' (P. Burgess, Trans.). London: Pluto Press, 1977.

Rubin, I. I. (1928). Essays on Marx's theory of value (M. Sanardžija \& F. Perlman, Trans.). Montréal - New York: Black Rose Books, 1973.

Samuelson, P. A. (1970). The "transformation" from Marxian "values" to competitive "prices": A process of rejection and replacement. Proceedings of the National Academy of Sciences, $67(1), 423-425$.

Samuelson, P. A. (1971). Understanding the Marxian notion of exploitation: A summary of the socalled transformation problem between Marxian values and competitive prices. Journal of Economic Literature, 9(2), 399-431.

Samuelson, P. A. (1973). Samuelson's "reply on Marxian matters". Journal of Economic Literature, 11(1), 64-68.

Samuelson, P. A. (1974a). Insight and detour in the theory of exploitation: A reply to Baumol. Journal of Economic Literature, 12(1), 62-70. 
Samuelson, P. A. (1974b). Rejoinder: Merlin unclothed, A final word. Journal of Economic Literature, 12(1), 75-77.

Samuelson, P. A. (1982). The normative and positivistic inferiority of Marx's values paradigm. Southern Economic Journal, 49(1), 11-18.

Seton, F. (1957). The transformation problem. Review of Economic Studies, 25, 149-160.

Smith, A. (1776). An inquiry into the nature and causes of the wealth of nations. London: Everyman's Library, 1991.

Smith, T. (1993). Marx's Capital and Hegelian dialectical logic. In F. Moseley (Ed.), Marx's method in Capital: a reexamination. New Jersey: Humanities Press.

Sraffa, P. (1960). Production of commodities by means of commodities: Prelude to a critique of economic theory. Cambridge: Cambridge University Press, 1963.

Steedman, I. (1977). Marx after Sraffa. London: New Left Books.

Winternitz, J. (1948). Values and prices: A solution of the so-called transformation problem. Economic Journal, 58, 276-280. 